\title{
Correlation between Local Eid-al-Fitr Homecoming (Mudik) with Coronavirus Disease-19 during Ramadhan Season Amidst Large-scale Social Distancing in Indonesia
}

\author{
Meita Veruswati ${ }^{1,2}$, Al Asyary $^{2,3 *}$, Rony Darmawansyah Alnur ${ }^{1}$, Guspianto Guspianto ${ }^{4}$ \\ ${ }^{1}$ Department of Public Health Science, Faculty of Health Sciences, Universitas Muhammadiyah Prof. Dr. Hamka, Jakarta, \\ Indonesia; ${ }^{2}$ Center of Educational and Community Services (P3M), Universitas Indonesia, Depok, Indonesia; ${ }^{3}$ Department of \\ Environmental Health, Faculty of Public Health, Universitas Indonesia, Depok, Indonesia; ${ }^{4}$ Study Program of Public Health \\ Science, Faculty of Medicine and Health Sciences, Universitas Jambi, Muaro Jambi, Indonesia
}

\begin{abstract}
BACKGROUND: In anticipation of coronavirus disease (COVID)-19's transmission peak, Eid-al-Fitr homecoming (mudik) has officially been banned by the Indonesian government interlocal but not local in welcoming this religious Muslim celebration. This local Mudik is held by traveling among regional provinces and is still allowed by each local government, including Java, which has the highest transmission of COVID-19 in Indonesia.

AIM: This study aims to present the difference between COVID-19 status before and during local Mudik on Java during Ramadhan with the implementation of large-sale social distancing applied in Jakarta, Indonesia.

METHODS: This research was employed by secondary data analysis that was obtained from surveillance data from related authorities, including the Ministry of Health and all local governments of Java, which consisted of four provinces and Jakarta. Incidence and suspect statuses of COVID-19, which were examined in the study, were presented in daily rates with before and during local Mudik in four provinces: Jawa Barat, Yogyakarta, Banten, and Jawa Tengah.

RESULTS: The number of positive confirmed patients differed significantly with before and during local Mudik $(p<0.05$; mean difference $=-$ /negative values $)$.

CONCLUSION: This study's findings showed that the local Mudik increased the number of COVID-19 cases in four provinces in Java, which these provinces were designated as Mudik destinations by travelers coming from Jakarta during the end of Ramadhan season.
\end{abstract}

Edited by: Mirko Spiroski Citation: Veruswati M, Asyary A, Alnur RD, Guspianto G. Correlation between $\mathrm{L}$ - Asy Eid-al-Fitr Homecoming (Mudik) with Coronavirus Disease-19 during Ramadhan Season Amidst Large-scale Social Distancing in Indonesia. Ope Access Maced J Med Sci. 2021 Dec 20; 8(T1):570-573. https://doi.org/10.3889/oamjms.2021.5369 Keywords: Coronavirus; Homecoming; Religious trave Social distancing; Eid-al-Fit *Correspondence: Al Asyary, Department of Ersitas Indonesia, CBuilding $2^{\text {nd }}$ Floor Kampus FKM-UI, Depok, 16424, Indonesia E-mail: al.asyary@ui.ac.id Received: 10-Aug-2020 Revised: 06-Jan-202 Accepted: 07-Jan-202 Copyright: ๑ 2020 Meita Veruswati, Al Asyary, Rony Darmawansyah Alnur, Guspianto Guspianto Funding: Publication of this article was financially supported by the Scientific Foundation SPIROSKI, Skopje, Republic of Macedonia Competing Interests: The authors have declared that no
competing interests under the terms of the Creative Commons Attribution-
NonCommercial 4.0 International License (CC BY-NC 4.0)

\section{Introduction}

Coronavirus disease (COVID)-19 is a well-known infectious disease that is borne rapidly across the globe [1], [2]. When COVID-19 cases were first reported China was celebrating the Chinese New Year, an event that potentially drove the disease around the world [3], [4]. The many people travelling home from around the world enabled mass gatherings of big families, which transmitted the virus from where they lived [5]. This also happened in the hajj [6] and the Eid-al-Fitr celebration after the month of Ramadhan for Muslims in Indonesia.

The Eid-al-Fitr homecoming (mudik) is a routine and temporary migration in Indonesia, a country known for having the largest Muslim population in the world [7]. This migration is massive and done by long and short-distance travelers in celebrating the Eid-al-Fitr with family [8], which mass gathering is also potentially happening at this circumstance [9]. Mudik season usually lasts from the $1^{\text {st }}$ day of Ramadhan until day one before (D-1) the month of Syawal, which has the Eid-alFitr celebration on the Islamic calendar of Hijr.

There are four provinces that are usually designated as Mudik destinations in Indonesia, all of which are located on Java [10]. Jawa Barat, Special Region of Yogyakarta (DIY), Banten, and Jawa Tengah experienced more than $50 \%$ of all Mudik travelers, leaving from the capital city of these provinces including Bandung (Jawa Barat), Yogyakarta City (DIY), Tangerang (Banten), and Semarang (Jawa Tengah) [11] - to the center of COVID-19 pandemic in Java. In fact, these capitals contributed the most Mudik travelers to the area known as the capital and the center of business in each province, as well as Indonesia. These capitals of the provinces were also designated as Mudik destinations by travelers coming from other Indonesian regions, as well as from travelers and repatriations from abroad [11]

Since this Indonesian religious custom is a mass gathering that risks the spread of COVID-19, the Indonesia government banned all Ramadhan 
celebration activities using large-sale social distancing (LSSD) measures in this region. Although it was banned nationally, local Mudik was still allowed [12]. Since local Mudik potentially blew up COVID-19 transmission, evidence of it related to COVID-19 incidence rate is essential to know, particularly during this hardest time of the COVID-19 pandemic.

\section{Methods}

\section{Study area}

Four provinces have become local Mudik destinations in Java, Indonesia: Jawa Barat, Yogyakarta, Banten, and Jawa Tengah. These regions, including all Indonesian territories, face Mudik season, which started on $1^{\text {st }}$ Ramadhan 1442 in the Islamic calendar of Hijriah - or April 24, 2020. This temporary travelling lasted until the end of Ramadhan or day one before (D-1) Eid-alFitr, which on this year falls on May 24, 2020.

Instead of applying "lockdown," a policy that consists of the full closure of all activities and entryexit in a territory to cut down the transmission of COVID-19 [13], [14], the Indonesian government is applying LSSD. LSDD defined as massive restrictions in response to the COVID-19 pandemic that is followed by public place closures, public transportation restrictions, and a travel ban on leaving or entering a region. Other restrictions also include the disallowance of onlineordered motorcycle taxis (ojek) from carrying passengers (they are only allowed to carry food and goods), restricted dine-in at food cafes/restaurants (only takeaway is allowed), and the closure of all shops and workplaces except for those supplying basic needs. Places being shut down also include schools, worship places like mosques, and entertainment sites. LSSD measures consist of public transportation operating at $50 \%$ capacity [12]. This policy is still being carried out in several regions, particularly those with a high index of transmission, including Jakarta and most territories on Java.

\section{Data collection}

A COVID-19 dataset that ran from 6 March to May 16, 2020 was derived from each provincial authority, namely, Jawa Barat, Yogyakarta, Banten, and Jawa Tengah. In this study, local Mudik was measured in the month of Ramadhan based on the Islamic calendar, ranging from 24 April to May 2, 2020. The daily incidence and suspected cases of COVID-19 came from the local government public data for COVID-19. These data were collected according to LSSD, which started on April 10, 2020. This means that before LSSD implementation ranged from March 2 to April 9, 2020, while on-going LSSD was implemented starting on April 10,2020 , of the dataset.

\section{Data analysis}

An independent sample t-test was performed to analyze the mean difference according to normality data distribution ( $p$ value of Kolmogorov-Smirnov test $>0.05$ ). The test was performed to present the mean difference between continue/numeric and discrete/categorical variables with two-tailed $95 \%$ confidence interval or $5 \%$ alpha and $80 \%$ power of tests. The difference between the before and during local Mudik season in Ramadhan season, while LSSD was implemented was assumed when there was a mean difference between these groups in determining the number of COVID-19 positive cases and suspected cases.

\section{Results}

According to Figure 1, both incidence and suspected cases of COVID-19 increased from before and during the local Mudik in Java during Ramadhan, while LSSD was applied in Jakarta. This shows that both incidence and suspected cases of COVID-19 increased daily since LSSD was first implemented in Jakarta.

Table 1 shows that suspected cases of COVID-19 did significant from before and during local Mudik in Yogyakarta Province. Meanwhile, incidence cases of COVID-19 did significant from before and during local Mudik in all provinces in Java, Indonesia.

Table 1: Independent-t-test's mean difference between before and during local Mudik in Java, Indonesia

\begin{tabular}{|c|c|}
\hline COVID-19 status & Independent-t-test's mean difference \\
\hline \multicolumn{2}{|c|}{ Jawa Barat Province } \\
\hline Incidence & $-21.041^{*}$ \\
\hline Suspect & -23.940 \\
\hline \multicolumn{2}{|c|}{ Yogyakarta Province } \\
\hline Incidence & $-2.852^{\star \star}$ \\
\hline Suspect & $-511.712^{\star \star}$ \\
\hline \multicolumn{2}{|l|}{ Banten Province } \\
\hline Incidence & $-4.622^{* *}$ \\
\hline Suspect & 6.538 \\
\hline \multicolumn{2}{|c|}{ Jawa Tengah Province } \\
\hline Incidence & $-14.915^{\star \star}$ \\
\hline \multicolumn{2}{|c|}{ Jawa Barat Province } \\
\hline Incidence & $-21.041^{*}$ \\
\hline Suspect & -23.940 \\
\hline \multicolumn{2}{|c|}{ Yogyakarta Province } \\
\hline Incidence & $-2.852^{\star *}$ \\
\hline Suspect & $-511.712^{\star \star}$ \\
\hline \multicolumn{2}{|l|}{ Banten Province } \\
\hline Incidence & $-4.622^{\star \star}$ \\
\hline Suspect & 6.538 \\
\hline
\end{tabular}

\section{Discussion}

Being the region with the biggest Muslim population in the world, Indonesia has the potential to massively spread COVID-19 during the Mudik season [15]. In this period of time, Java usually has 


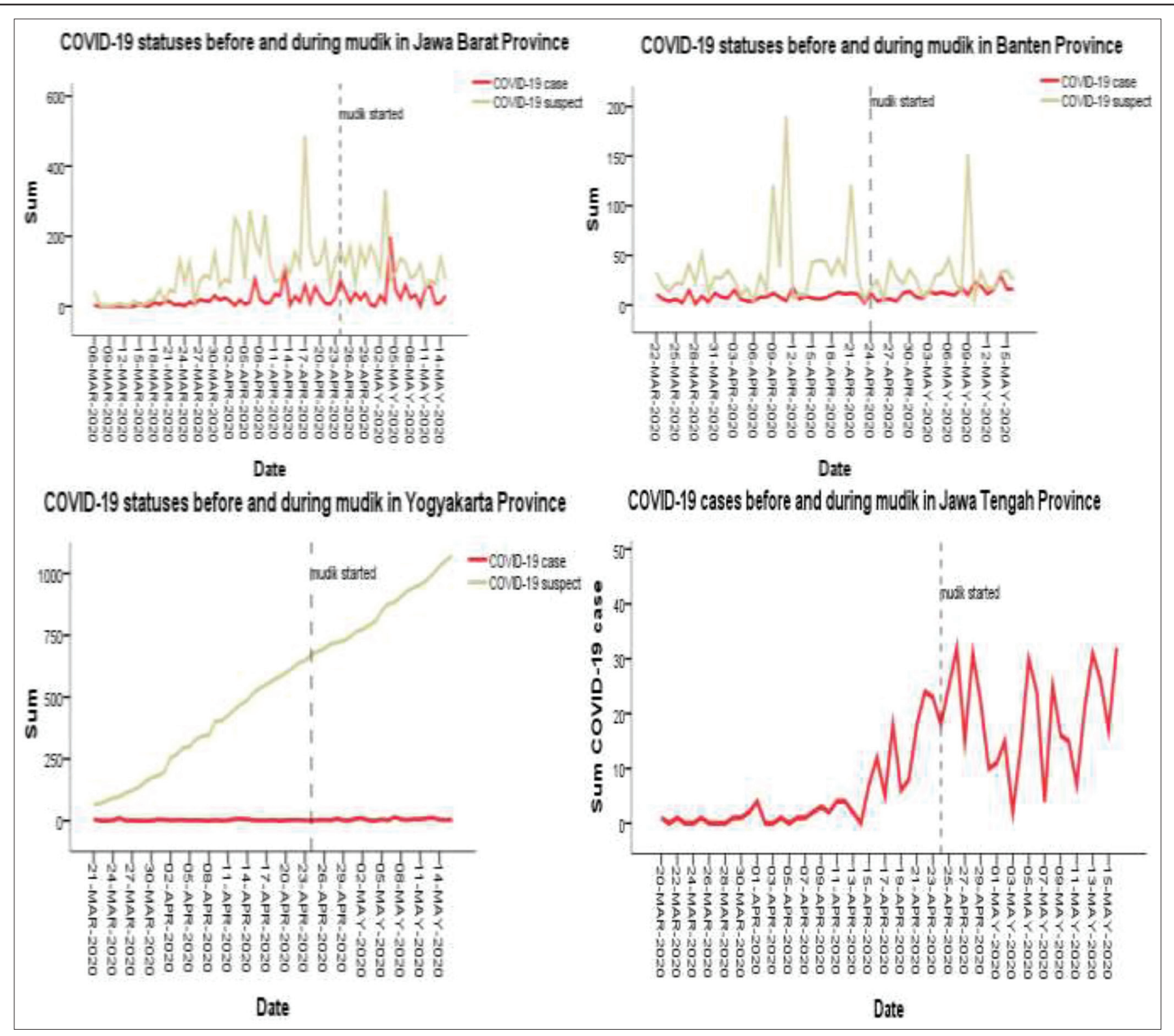

Figure 1: Coronavirus disease-19 statuses before and during local Mudik in four provinces in Java

a high number of local Mudik travelers who could potentially increase the number of COVID-19 incidence this season [11]. In fact, most of Java's local Mudik travelers come from pandemic centers, including each of the province capitals, as these are the entry point areas for those travelling from abroad [16].

In this study, we found that the local Mudik season was related to more cases of COVID-19 among this population (negative value of mean difference). This result is in line with previous evidence that traditional celebration is associated with the spread of COVID-19, which increases COVID-19 incidence rates [3], [4], [17]. At the same time, in other related circumstances in the Middle East, Iraq, has reported higher COVID-19 incidence rate than Saudi Arabia and Kuwait, but lower than Iran, Turkey, and Jordan. This scenario can help us improve the pandemic incidence rate when we welcome the Eid-al-Fitr [18].

Sitting in the western part of Indonesia, Java has the most complete, hybrid, and multiple modes of transportation than any other part of Indonesia [19], [20]. Zones included in this area contain three provinces that are namely Jawa Barat, Banten, and Jawa Timur. People that originate from these buffer regions are able to travel around the regions, particularly leaving and entering the capital city of these provinces [21], [22].

Since they are easily connected to these zones, people who originated from around Java traveled home when Mudik started to apply on April 27, 2020. This Muslim tradition is a time to seek forgiveness from relatives, especially from core families, and then welcoming the victory day as Eid-al-Fitr day [23]. Local Mudik not only attracted travelers for the Eid-al-Fitr celebration, but they also enjoyed a vacation with their visit to their hometown [24].

Despite the significant finding of how local Mudik during LSSD in Jakarta during is related with COVID-19 incidence rates, this study has limitations. The incident rate of COVID-19 could be affected by the effectiveness of travel bans, which varied by the district 
and by how provincial local governments applied the LSSD. In addition, the travel ban has not optimally applied before implementation of LSSD, as it allowed travelers to go back to their hometown permanently due to the joblessness created by the COVID-19 pandemic.

\section{Conclusion}

This study shows that Mudik was significantly associated with COVID-19 incidence among the population in Java, Indonesia, during Ramadhan with LSSD implementation in Jakarta. This preliminary study needs to be further developed, as Mudik could potentially increase COVID-19 incidence not only in Indonesian Muslims but also in other countries, religions, and cultures, especially in homecoming travel traditions during this pandemic.

\section{References}

1. World Health Organization. Coronavirus Disease 2019 (COVID-19): Situation Report No. 72. Geneva: World Health Organization; 2020.

2. Asyary A, Veruswati M. Sunlight exposure increased COVID-19 recovery rates: A study in the central pandemic area of Indonesia. Sci Total Environ. 2020;729:139016. https://doi. org/10.1016/j.scitotenv.2020.139016 PMid:32361458

3. Fan C, Cai T, Gai Z, Wu Y. The relationship between the migrant population's migration network and the risk of COVID-19 transmission in China-empirical analysis and prediction in prefecture-level cities. Int $\mathrm{J}$ Environ Res Public Health. 2020;17(8):2630. https://doi.org/10.3390/ijerph17082630 PMid:32290445

4. Chen S, Yang J, Yang W, Wang C, Bärnighausen T. COVID-19 control in China during mass population movements at New Year. Lancet. 2020;395(10226):764-6. https://doi.org/10.1016/ s0140-6736(20)30421-9

PMid:32105609

5. Ebrahim SH, Memish ZA. COVID-19-the role of mass gatherings. Travel Med Infect Dis. 2020;34:101617. https://doi. org/10.1016/j.tmaid.2020.101617

PMid:32165283

6. Rustika R, Oemiati R, Asyary A, Rachmawati T. An evaluation of health policy implementation for hajj pilgrims in Indonesia. J Epidemiol Glob Health. 2020;10(4):263-8. https://doi. org/10.2991/jegh.k.200411.001

PMid:32959605

7. Arribathi $\mathrm{AH}$, Aini Q, Raharja DS. Homecoming (mudik) in cultural and religion perspectives. J Cyberpreneursh Innov Creat Exact Soc Sci. 2018;4(1):45-52. https://doi.org/10.33050/ cices.v4i1.475

8. Iriany IS, Pasciana R, Ramdhani A. Eid homecoming "Mudik" tradition as a conventional pattern in the global era. J Adv Res
Soc Sci Humanit. 2019;4(3):129-35. https://doi.org/10.26500/ jarssh-04-2019-0306

9. McCloskey B, Zumla A, Ippolito G, Blumberg L, Arbon P, Cicero $A$, et al. Mass gathering events and reducing further global spread of COVID-19: A political and public health dilemma. Lancet. 2020;395(10230):1096-9. https://doi. org/10.1016/s0140-6736(20)30681-4 PMid:32203693

10. Hambali B. The management of Eid-al-Fitr mudik traffic flows. J Litbang POLRI. 2019;22(3):372-94.

11. Direktorat Jenderal Perhubungan Darat. Perhubungan Darat Dalam Angka. Jakarta: Direktorat Jenderal Perhubungan Darat; 2018. Available from: http://www.hubdat.dephub.go.id/data-ainformasi/pdda/2843-tahun-2018. [Last accessed on 2020 Apr 23]. https://doi.org/10.25104/warlit.v29i2.581

12. Indonesian National Task Team Force for Coronovirus 2019 (COVID-19). Coronovirus 2019 (COVID-19) in Indonesia. Jakarta: Indonesian National Task Team Force for Coronovirus; 2020. Available from: https://www.covid19.go.id. [Last accessed on 2020 Apr 23].

13. El-Malky AM, Al-Kathiri WH, El Nouman AA. When shal Coronavirus disease-19 stop? Review of literature. Open Access Maced J Med Sci. 2020;8(T1):75-81. https://doi.org/10.3889/ oamjms.2020.4844

14. Zareipour M, Kalejahi JN. The role of social participation in controlling and preventing of Coronavirus 2019 disease in Iran. Open Access Maced J Med Sci. 2020;8(T1):134-6. https://doi. org/10.3889/oamjms.2020.4956

15. Yulianto VI. Is the past in another country? A case study of rural-urban affinity on mudik lebaran in Middle Java. J Indones Soc Sci Humanit. 2012;4:49-66. https://doi.org/10.14203/jissh. v4i0.118

16. Prasetyo D, Sofyan L. Altering Intention to Mudik during COVID19 Pandemic: A Salient Cue and Simple Reminder Treatment No.3595007; 2020. https://doi.org/10.2139/ssrn.3595007

17. Alnur RD, Veruswati M, Asyary A. Has it done properly? The difference between before and after social distancing's policy implementation in controlling COVID-19 in Jakarta, Indonesia. In: E3S Web of Conferences, EDP Sciences; 2020. p. 12031. https://doi.org/10.1051/e3sconf/202020212031

18. Sarhan AR, Flaih MH, Hussein TA, Hussein KR. Nove Coronavirus (COVID-19) Outbreak in Iraq: The First Wave and Future Scenario, medRxiv; 2020. https://doi. org/10.1101/2020.06.23.20138370

19. Asmawi A. Civil prosperity and the implementation of ocean transportation policy in Jawa Barat Province. TEMALI J Pembang Sos. 2018;1(1):85-99. https://doi.org/10.15575/ jt.v1i1.2381

20. Asyary A, Prasetyo A, Eryando T, Mahendradhata $\mathrm{Y}$ Predicting transmission of pulmonary tuberculosis in Daerah Istimewa Yogyakarta Province, Indonesia. Geospat Health. 2019;14(1):171-7. https://doi.org/10.4081/gh.2019.673

21. Herdianti S, Permana A. Train and Eid-al-Fitr mudik tradition in Bandung on 1980-2014. Hist Madania J IImu Sej. 2018;2(2):111-34.

22. Lyseptiano M, Putranto LS. Characteristic of transportation during Eid-al-Fitr on respondents whom still had parents in Greater Area of Jakarta (Jabodetabek). JMTS J Mitra Tek Sipil. 2019;2(1):143-9. https://doi.org/10.24912/jmts.v2i1.3419

23. Hariyatmi $S$. The longing for the beloved: Mystical journey behind the homecoming tradition on EID al-fitr in Indonesia and songkran inthailand. Int J Humanit Stud. 2019;2(2):134-40.

24. Oktavio A, Indrianto AT. Social economic perspectives of homecoming tradition: An Indonesian context. KATHA Off $\mathrm{J}$ Cent Civilisational Dialogue. 2019;15(1):46-65. https://doi. org/10.22452/katha.vol15no1.3 